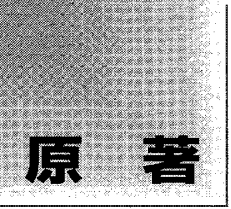

1996年 7論文26受付

論文受理

1997年6月16日

Code No.25 1

\section{螺旋状スキャンCTにおける線量指数(HTDI: helical scanning computed tomography dose index)の新しい概念と测定}

\author{
村松禎久・花井耕造・勝田昭一・藤田智之
}

\section{1. はじめに}

X線CT(以下, CT)における線量評価は二つの立場 から行わねばならず，混同してはならないと報告1さ れている。その立場とは，一つはCT検査に伴う患者 被曝線量の評価であり，もう一方はCT装置の性能評 価・管理のための線量評価である。ここでは，後者の 立場から線量評価法を議論する。

CT装置の性能評価・管理において，線量評価は特に 重要な項目である。従来(以下, コンベンショナル)ス キャンにおける線量評価 ${ }^{2}$ (4) は, computed tomography dose index（以下，CTDI）またはmultiple scan average dose (以下, MSAD)により行われてきた。ここで CTDIとは，シングルスキャンの体軸(以下，Z軸)上の 線量プロフィールの積分值 (以下, 線積分線量)を, 設 定スライス厚(以下，スライス厚)とシングルスキャン により生成される画像数で除したものと定義3されて いる(式(1))。言い替えれば，シングルスキャンにお いて 1 枚の画像を得るのに必要な線量をスライス厚で 補正した值を意味する，積分する範囲は，スライスの 中心からZ軸上ー7Tから7Tである。測定システムとし ては，円柱のアクリルファントムとペンシル型電離箱 線量計との組み合わせが使用4 7) されている。また，

\title{
New Concept and Procedure for Helical CT Dose Index
}

\author{
YOSHIHISA MURAMATSU • KOUZOU HANAI • SYOUICHI KATSUTA and YASUYUKI FUJITA \\ Department of Radiology, National Cancer Center Hospital
}

Received Jul.26,1996; Revision accepted Jun.16,1997; Code No.251

\section{Summary}

Standard dose evaluation methods have not yet been developed for helical scanning in x-ray computed tomography. This report describes a new concept in dose evaluation, the helical computed tomography dose index (HTDI). The center of a cylindrical phantom, separated from the patient couch, is set as the rotational center. A pencil-type ionizaion chamber is inserted into the phantom, and the integral dose is evaluated for a change in the scanning range. Measurement is performed at the center of the phantom and $1 \mathrm{~cm}$ inward from the surface of the phantom. The integral dose is substituted into an arithmetic expression to calculate the HTDI. The obtained HTDI is directly comparable to the computed tomography dose index (CTDI) obtained using a conventional dose evaluation system, and can therefore serve as a dose index specific to helical scanning.

Key words: Computed tomography $(X-C T)$, Helical scan, Dose evaluation, CT dose index $(C T D I)$, Helical scanning CT dose index (HTDI) 
任意のテーブル移動間隔(以下，テーブル間隔)でコン ベンショナルスキャンを行ったときのその場の平均線 量は，スキャン数の増加とともに飽和するが，この飽 和したときの線量をMSADと定義 している，MSAD は，CTDIに対し式(2)の関係にある。

$$
C T D I=(1 / n T) \int_{-7 T}^{7 T} D(z) d z
$$

$$
M S A D=(T / I) \cdot C T D I
$$

$$
D(z) \text { : シングルスキャンの線量プロフィール }
$$$$
T \text { : スライス厚 }
$$$$
I \quad: \text { テーブル間隔 }
$$

$n$ ：1回のシングルスキャンに生成される画像

一方，螺旋状(以下，へリカル)スキャンにおける線 量評洒法については，コンベンショナルスキャンとは 明らかにスキャン方式が異なるにもかかわらず，現在 までに規格化されていない.

本報告では，積分線量を元に算出する，ヘリカルスキ ヤンCTにおおる線量指数 (helical scanning CT dose index : HTDI)の新しい概念とその測定について述べる.

なお，積分線量とは，任意のスキャン設定範囲(以 下，スキャン範网)についてスキャンを行ったときのZ 軸上の線量プロフィールの積分值と規定する。また， スキャン範用 $x$ における積分線量 $I D(x)$ より算出した コンベンショナルスキャンCTの線量指数をCTDI (x), 同様にヘリカルスキャンCTの線量指数をHTDI (x)と表示する.

\section{2. 方 法}

\section{2-1 使用機器}

使用機器を下記に示す。

・ CT専用線量測定システム

$$
\begin{array}{ll}
\text { トモラドシステム } & \text { (CAPINTEC }) \\
\text { 線量計 } & : 192 \mathrm{X} \\
\text { チェンバ } & : \mathrm{PC}-4 \mathrm{P}(1.2 \mathrm{~cm} \phi \times 10 \mathrm{~cm}, 3 \mathrm{ml}) \\
\text { ファントム } & : \operatorname{PP}-8 \mathrm{~T}(16 \mathrm{~cm} \phi \times 15 \mathrm{~cm})
\end{array}
$$

\section{- X線CT装置}

TCT-900S Super Helix（株式会社東芝製）

\section{2-2 積分線量の測定}

Fig.1は，積分線量測定における幾何学的配置図を示 したものである。発砲スチロールを利用し，ファント ムを患者テーブルと完全に独立させて回転中心に固定
し，スキャン範囲 2 $14 \mathrm{~cm}$ について，コンベンショナ ルスキャンおよびへリカルスキャンを行う。

スキャン条件を下記に示す、測定点は，ファントム の中心および表面から $1 \mathrm{~cm}$ 内側 (以下，表面)とし，表 面については，0，90，180，270度の位置での 4 点の 平均を測定值とする。また，使用したCT装置は任意 の管球角度からX線が発生するため，目視でスキャン 開始角度を 0 度となるように測定を行った。

な技，へリカルスキャンに拟いてスキャン速度当た りのテーブル移動速度，つまり1回転(360度)当たり のテーブル移動距離をスライス厚で除したものをピッ チ ${ }^{89}$ ' と呼び，下記のように規定する。また，各測定 值は，X線の実効エネルギー70 keVに扔けるアクリル の吸収線量变換係数"を乗じて積分線量とする。

・スキャン条件

$$
\begin{aligned}
& \text { コンベンショナルスキャン } \\
& 120 \mathrm{kV}, 200 \mathrm{~mA}, \text { スキャン時間 }: 1 \mathrm{~s} \\
& \text { スライス厚 } \quad: 0.5,1 \mathrm{~cm} \\
& \text { テーブル間隔 }: 0.5,1 \mathrm{~cm} \\
& \text { ヘリカルスキャン }
\end{aligned}
$$

$120 \mathrm{kV} ， 200 \mathrm{~mA}$ ，スキャン速度：1 $1 \mathrm{~s} /$ rot. スライス厚 $: 0.5,1 \mathrm{~cm}$

テーブル移動速度（以下，テーブル速度）：

$0.5,0.75,1,1.5,2 \mathrm{~cm} / \mathrm{s}$

・ピッチと積分線量

ピッチ =テーブル移動距離/360度/スライス厚 $I D(x)=f \cdot R(x)$

$I D$ : 積分線量 $[\mathrm{cGy} \cdot \mathrm{cm}]$

$x$ ：スキャン範进 $[\mathrm{cm}]$ （ただし， $x$ は自然数）

$f$ : 実効エネルギー70keVにおけるアクリ ルの吸収線量変換係数 $(=0.78[\mathrm{cGy} / \mathrm{R}])$

$R$ ：測定值 (線量計の読み値) $[\mathrm{R} \cdot \mathrm{cm}]$

\section{2-3 HTDIの算出}

2-2で測定される各スキャン範囲における積分線量 より，下記の算出式に従ってCTDI $(\mathrm{x})$ およびTDI $(\mathrm{x})$ を算出する。

・コンベンショナルスキャン

$$
\operatorname{CTDI}(x)=(1 / n(x+T)) \cdot I D_{\text {conv. }}(x)
$$

・ヘリカルスキャン

$$
\operatorname{HTDI}(x)=(1 /(x+T)) \cdot I D_{\text {helical }}(x)
$$

注釈：：現在，CT装置の実効エネルギーは公表されていない．また，ファントム中の実効エネルギーも不詳である．そこで，本 諭文では文献より実効エネルギー70 keVにおけるアクリル吸収線量变換係数で变換した．今後，CTにおける実効エネル ギー測定法の確立により係数が変化しても換算は可能である。 


$$
\begin{aligned}
& I D_{\text {conv. }}: \text { コンベンショナ } \\
& \\
& \text { ルスキャンの積 } \\
& \\
& \text { 分線量 }[\mathrm{cGy} \cdot \\
&\mathrm{cm}] \\
& I D_{\text {helical }}: \text { ヘリカルスキャ } \\
& \text { ンの積分線量 } \\
& {[\mathrm{cGy} \cdot \mathrm{cm}] }
\end{aligned}
$$

\section{3. 結 果}

3-1 スキャン範囲に対する 積分線量

Fig.2は，ファントムの中心 における積分線量について， コンベンショナルスキャンお よびヘリカルスキャンのピッ チを変化させたものである． 図中，横軸はスキャン範囲， 縦軸は 1 回転当たり $100 \mathrm{mAs} \mathrm{s}^{\#}$

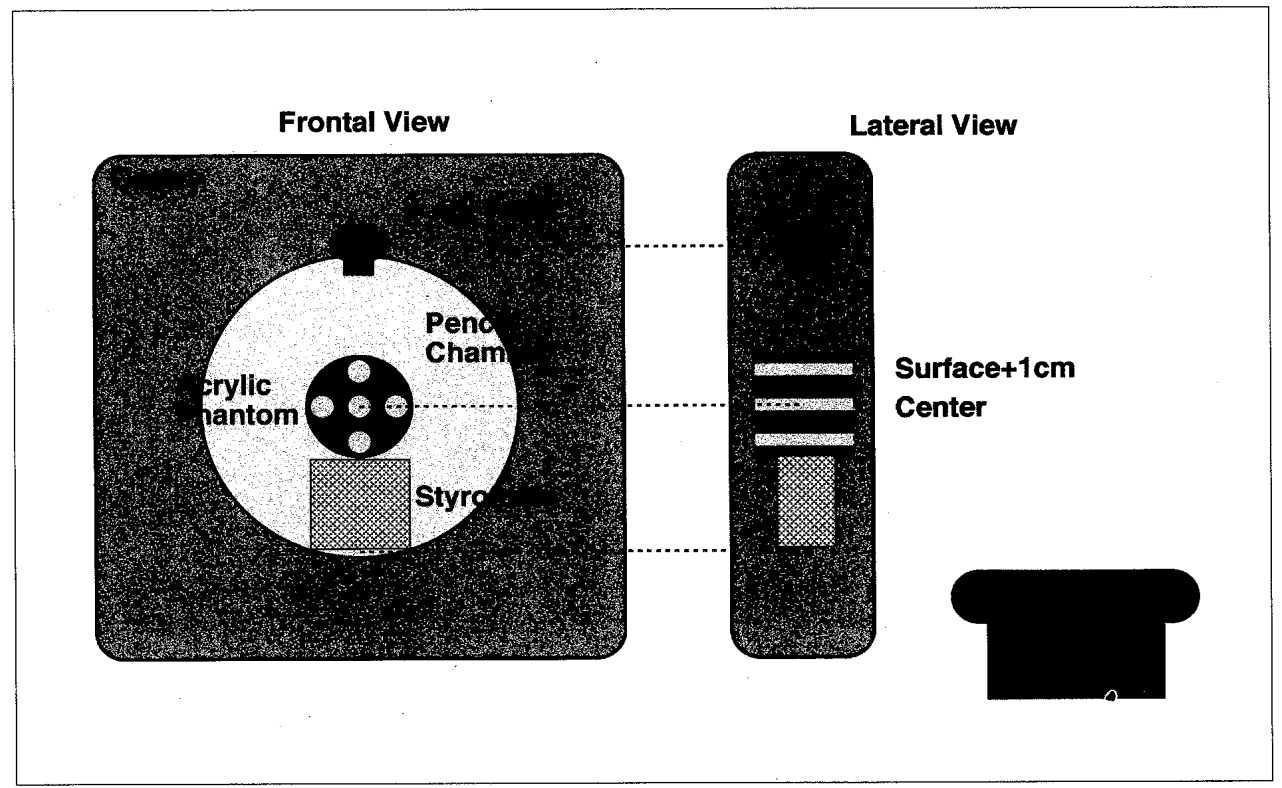

Fig. 1 Geometrical arrangement for integral dose measurement. The phantom should be separated from the patient couch using styrofoam.

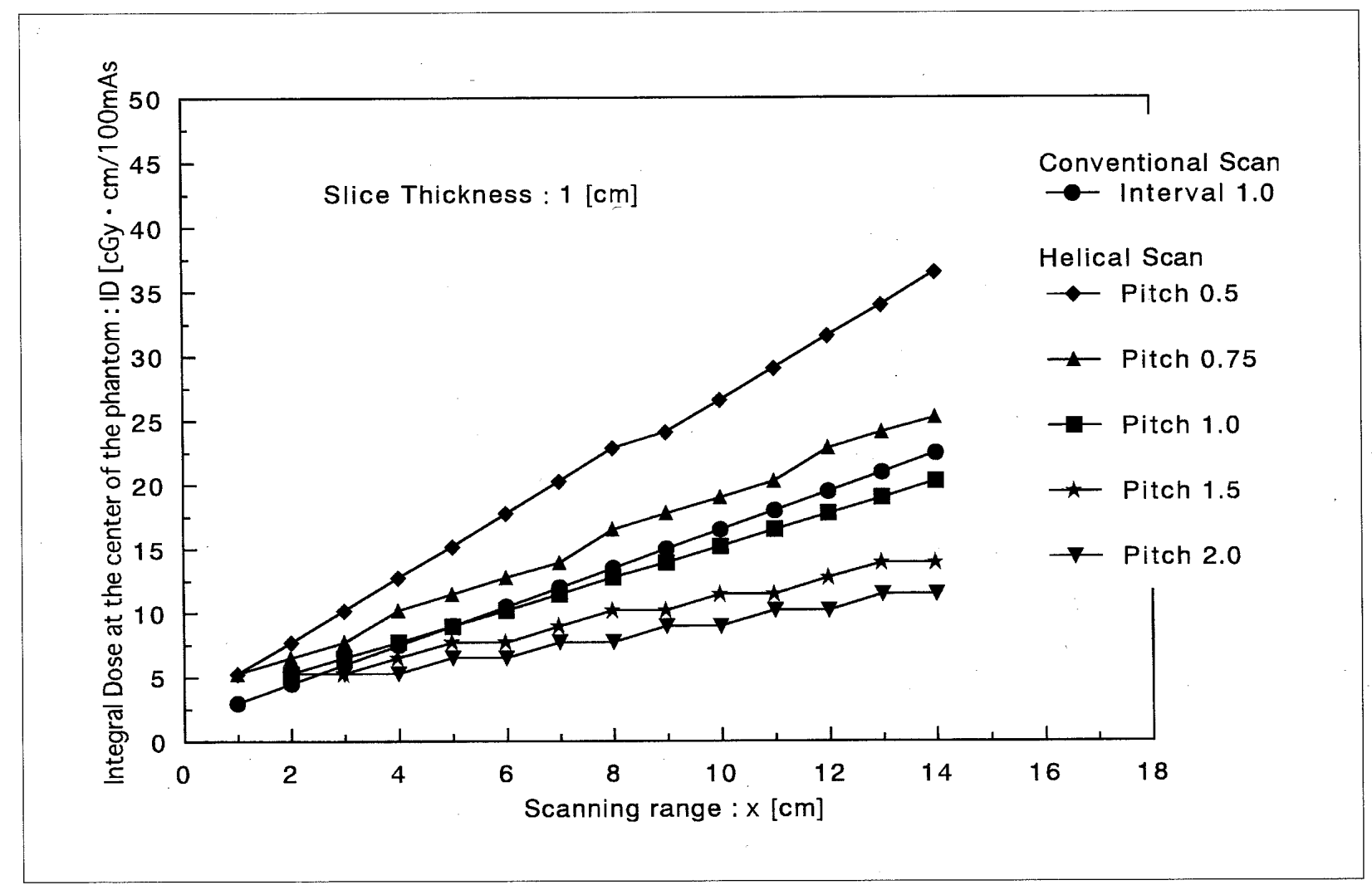

Fig. 2 Integral dose at the center of the phantom. Integral dose is expressed per $100 \mathrm{mAs}$. Here, 'mA' shows the $x$-ray tube current, and ' $s$ ' shows the scanning time per $360^{\circ}$ rotation.

[Remarks]

Tube voltage : $120 \mathrm{kV}$

$\mathrm{T}:$ Slice thickness $1 \mathrm{~cm}$

Interval : Couchtop sliding interval $(\mathrm{cm})$ in conventional scanning.

Pitch : Couchtop sliding distance per $360^{\circ}$ rotation divided by the nominal slice thickness in helical scanning.

注釈 \#\#：mAsは, 1 回転当たりのX線出力を表す.つまり, mAはX線管電流, $\mathrm{s}$ は全スキャンの総スキャン時間でなく, 1 回転 当たりのスキャン時間である. 
でスキャンしたとき(以下，100mAs当たり)の積分線 量に換算し表示した。 スライス厚は， $1 \mathrm{~cm}$ あ゙あ。

両スキャンとも，スキャン範囲の増加とともに積分 線量は規則的に増加した。コンベンショナルスキャン とへリカルスキャンのピッチ 1.00 比較では, スキャ ン範囲約 $5 \mathrm{~cm}$ を境に逆転しコンベンショナルスキャン の方が高い線量を示した。またフファントムの表面に おける積分線量についても同様の結果を得た。

\section{3-2 HTDI $(x)$ とCTDI $(x)$ の関係}

Fig.3は, Fig.2よりファントム中心において100mAs 当たりに換算したHTDI $(\mathrm{x})$ およびCTDI $(\mathrm{x})$ を算出した ものである。Fig.4は同様にファントム表面について 算出したものである。図中，横軸は久キャン範囲，左 の縦軸は各線量指数を絶対值で表示したもの，右の縦 軸はCTDIを 1 として正規化し，相対的に表示したも のである。

CTDI $(\mathrm{x})$ はスキャン範囲の変化に対して一定の值を とるが, $\operatorname{HTDI}(\mathrm{x})$ は規則的な変化とともに徐々に小さ な值をとりながら飽和する傾向を示した。また，コン ベンショナルスキャンとヘリカルスキャンのピッチ
1.0での比較では，ファントム中心ではスキャン範囲 約 $5 \mathrm{~cm}$ ，表面では約 $3.5 \mathrm{~cm}$ で同じ值を示した。

Tableは，Fig.3，4からスキャン範囲14cmに扔ける HTDIとCTDIの関係を相対的に示したものである。コ ンベンショナルスキャンとへリカルスキャンのピッチ 1.0での比較では，中心で約 $10 \%$ ，表面で約 $15 \%$ 程度 の線量低下を示した。またへリカルスキャンのピッ チとHTDIは反比例の関係を示した。

Fig.5は，スライス厚0.5，1 cmについて，ファント ム中心に抢ける $100 \mathrm{mAs}$ 当たりに換算したHTDI $(\mathrm{x})$ と $\mathrm{CTDI}(\mathrm{x})$ を比較したものである。図中の横軸，縦軸の 表示形式は，Fig.3，4 と同様である。CTDI (x)ではス ライス厚 $0.5 \mathrm{~cm}$ が大きな值をとるが, $\operatorname{HTDI}(\mathrm{x})$ では逆 に，テーブル速度に関係なくスライス厚 $1 \mathrm{~cm} の$ 方が大 きな值を示した。

\section{4. 考 察}

\section{4-1 積分線量の測定について}

ヘリカルスキャンCTに扔ける線量指数(HTDI)は, 前述のように，任意のスキャン範囲の積分線量をもと に算出するものである。まず，積分線量の測定意義と 万法について考察する。

著者らは過去の報告10 に扔いて，コンベンショ ナルスキャンおよびへリ カルスキャンの被曝形態 の比較から，コンベンシ ヨナルスキャンに対しへ リカルスキャンに扔ける 新たな線量因子は，テー ブル速度，補間再構成に 伴う線量增加㧍よび両ス キャンのX線投入および 遮断時 (以下, $\mathrm{X}$ 線スイッ チング)の回数差の三つで あることを示し，熱ルミ ネセンス線量計(以下, TLD）を使用した測定法を 提案している。 また本使 用CT装置では，前述の三 つの因子の他, コンベン ショナルスキャンの体動 補正ソフトによる線量増 加が報告いされている。 ただし，体動補正ソフト の影響はX線スイッチン グごとに生じることか ら，本論文ではX線スイ 
ッチングの回数差に含め

て考えることにする。

これらに対し，ある同一 スキャン範囲について両ス キャンを行い, 画像情報を 得ることを仮定したとき， 個々の線量因子の影響を評 価することも必要である が，スキャン全体としての 線量, つまり積分線量から 三つの線量因子を一元的に 評洒することが重要と考え ら扎る。また測定器につい ても，測定值の直読が可能 でかつ従来より使用されて いるペンシル型電離箱線量 計の使用か望まれる。今回 使用した線量測定システ ムは, NBS (National Bureau of Standard：米国) と トレーサビリティの関係に あり，シングルスキャンに よる測定値の繰り返し精度 も変動係数 CV $=1.0 \%$ 以下 (測定回数 10 回)と良好である.

しかし，積分線量の测定に対して従来のように患者 テーブルを用いてファントムを固定すると，スキャン 開始とともにファントムが移動し, X線ビームがペン シル型電離箱の有效電離領域から外れ, 結果的に線量 測定システムの感度低下を招き, 正確な測定は不可能 と考えられる。

この問題点に対しわれわれ は，Fig.1に示したように，患 者テーブルとファントムを完全 に独立して設置し，積分線量を 測定する方法を考案した。つま り，X線発生および患者テーブ ルの制御は，スキャンプログラ ムに従い通常通り動作をする が、ファントムと挿入されたペ ンシル型電離箱は完全に固定さ れた状態でスキャンが行われる ことになる。

なお，本測定法では患者テー ブルのX線吸収が測定值に影響 しないことになるが，性能評 価・管理上は問題にならない。

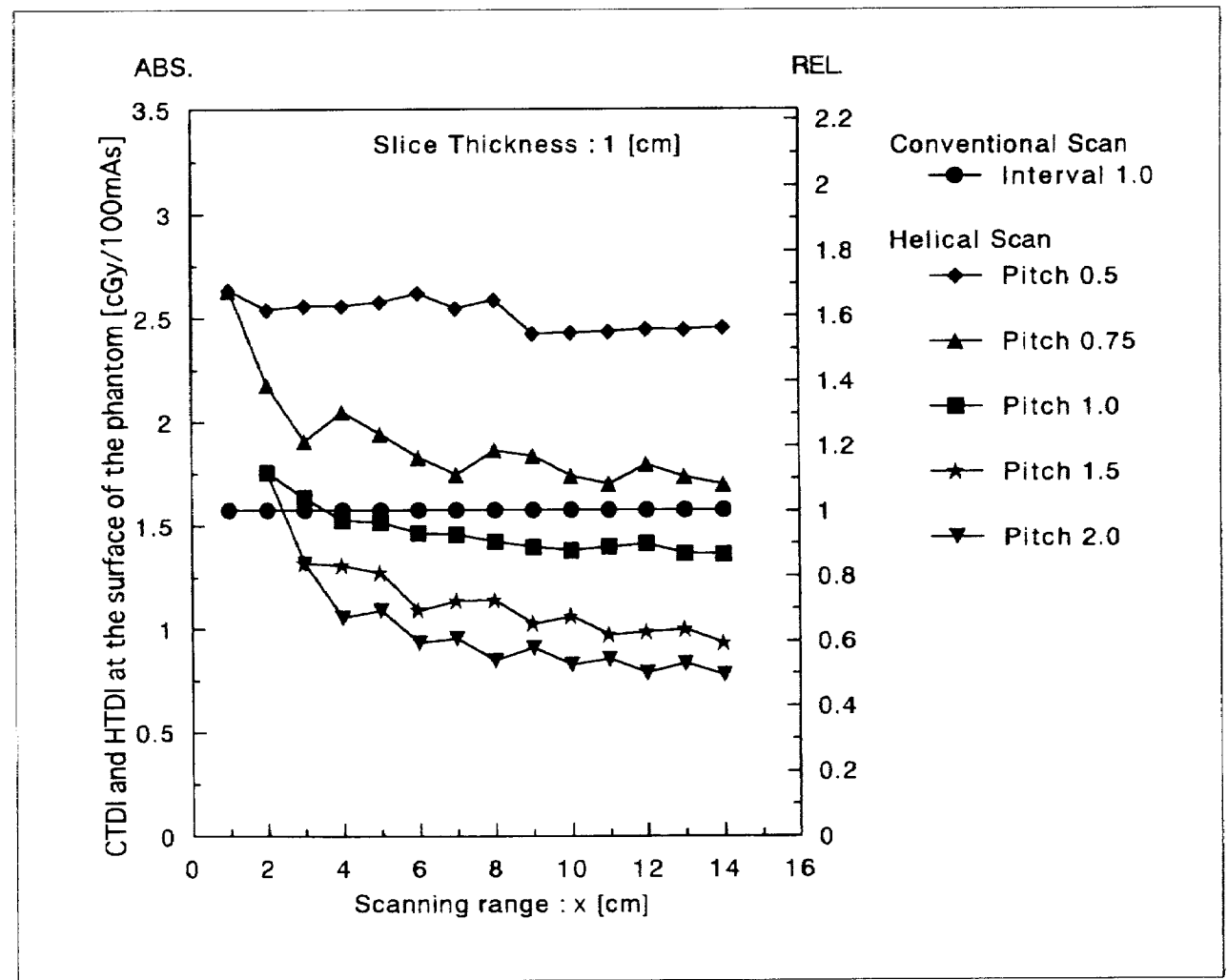

Fig. 4 HTDI $(x)$ s and CTDI $(x) s$ at the phantom surface. [Remarks]

Tube voltage $120 \mathrm{kV}$

$T$ : Slice thickness $1 \mathrm{~cm}$

These are displayed in the same manner as in Fig. 3.
ただし，発泡スチロールによるファントムの固定はX 線吸収率も約 $1 \%$ と低くかつ簡易的であるが，今後は 幾何学的配置の再現性を考慮し，本測定法専用の固定 具の作製が必要であると考える。

\begin{tabular}{|c|c|c|c|c|c|c|}
\hline \multirow[b]{3}{*}{ CTDI } & \multirow[b]{3}{*}{ (14) } & \multirow{2}{*}{$\begin{array}{c}\begin{array}{c}\text { Couchtop } \\
\text { factor }\end{array} \\
\text { Interval }\end{array}$} & Center & \multicolumn{3}{|c|}{$\begin{array}{l}\text { Surface } \\
+1 \mathrm{~cm}\end{array}$} \\
\hline & & & [cGy/100mAs] & $1.00^{*}$ & [cGy/100mAs] & $1.00^{*}$ \\
\hline & & $1.0 \mathrm{~cm}$ & 1.50 & $(1.11)$ & 1.57 & $(1.15)$ \\
\hline \multirow[t]{6}{*}{ HTDI } & (14) & Pitch & & & & \\
\hline & & 0.50 & 2.44 & $\begin{array}{c}1.63 \\
(1.81)\end{array}$ & 2.46 & $\begin{array}{c}1.57 \\
(1.81)\end{array}$ \\
\hline & & 0.75 & 1.68 & $\begin{array}{c}1.12 \\
(1.24)\end{array}$ & 1.70 & $\begin{array}{c}1.08 \\
(1.25)\end{array}$ \\
\hline & & 1.00 & 1.35 & ${ }^{0.90}(1.00)^{* *}$ & 1.36 & $c^{0.87}(1.00)^{* *}$ \\
\hline & & 1.50 & 0.93 & $\begin{array}{c}0.62 \\
(0.69)\end{array}$ & 0.93 & $\begin{array}{c}0.59 \\
(0.68)\end{array}$ \\
\hline & & 2.00 & 0.77 & $\begin{array}{c}0.51 \\
(0.57)\end{array}$ & 0.78 & $\begin{array}{c}0.50 \\
(0.57)\end{array}$ \\
\hline
\end{tabular}




\section{4-2 HTDIの定義と算出式について}

測定された積分線量の值では，従来のCTDIおよび MSADとは直接比較することはできない。そこでわれ われは，新たにへリカルスキャンCTにおけるHTDIを定 義した.ここで，HTDIの算出過程について考察する.

はじめに，スライス厚 $\mathrm{T}$ ステーブル間隔 $\mathrm{I}$ が等しい 場合(以下, $\mathrm{T}=\mathrm{I}$ )のコンベンショナルスキャンの積分 線量とCTDIの関係を考える。スキャン範囲 $x$ における コンベンショナルスキャンの積分線量 $I D(x)$ は，シン グルスキャン時の線積分線量とスキャン数 $m(x)$ の積で 式 (5)として表される。また，スキャン数 $m(x)$ は式 (6)，CTDIは前述のように式(1)となる。

$$
\begin{aligned}
& I D_{\text {conv }}(x)=m(x) \int_{-7 T}^{7 T} D(z) d z \\
& m(x)=(x / T)+1 \quad \cdots \cdots \cdots . .
\end{aligned}
$$

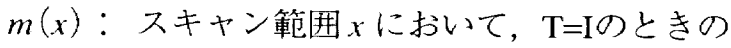
コンベンショナルスキャンのスキャン数

ここで式 (1)，(5)，（6）をまとめると，スキャン範 囲 $x$ のときCTDI $(\mathrm{x})$ は，2-3の中で記述した式(3)と して導出できる.また，CTDI $(x)$ はFig.3〜 5に示され たようにスキャン範囲の変化に対し一定であり，
CTDIと等しい.

$$
\begin{aligned}
\operatorname{CTDI}(x) & =(1 / n \operatorname{Tm}(x)) \cdot I D_{\text {conv. }}(x) \\
& =(1 / n(x+T)) \cdot I D_{\text {conr. }}(x) \\
& =C T D I
\end{aligned}
$$

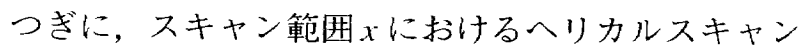
のHTDI $(\mathrm{x})$ について考える。前述したように，CTDI はシングルスキャンの線積分線量を生成される画像数 と設定スライス厚で補正したものであるので，へリカ ルスキャンについても同様に考え, 測定された積分線 量からシングルスキャンの線積分線量にあたる線量を 算出することを考える。市なわち，スキャン範囲 $x$ に おけるへリカルスキャンの積分線量 $I D(x)$ は，ある線 量 $H(x)$ とスキャン数 $m(x)$ の積と仮定する。また，算 出されるHTDIがCTDIと直接比較を可能とするため に，スキャン数を共通とする。つまりスキャン数 $m(x)$ は，スキャン範囲をスライス厚の間隔でコンベンショ ナルスキャンを行ったものとし，式(6)と同じとする.

$$
I D_{\text {helical }}(x)=m(x) \cdot H(x)
$$

また，CTDI $(\mathrm{x})$ に対応するHTDI $(\mathrm{x})$ はH $(x)$ を用いて，

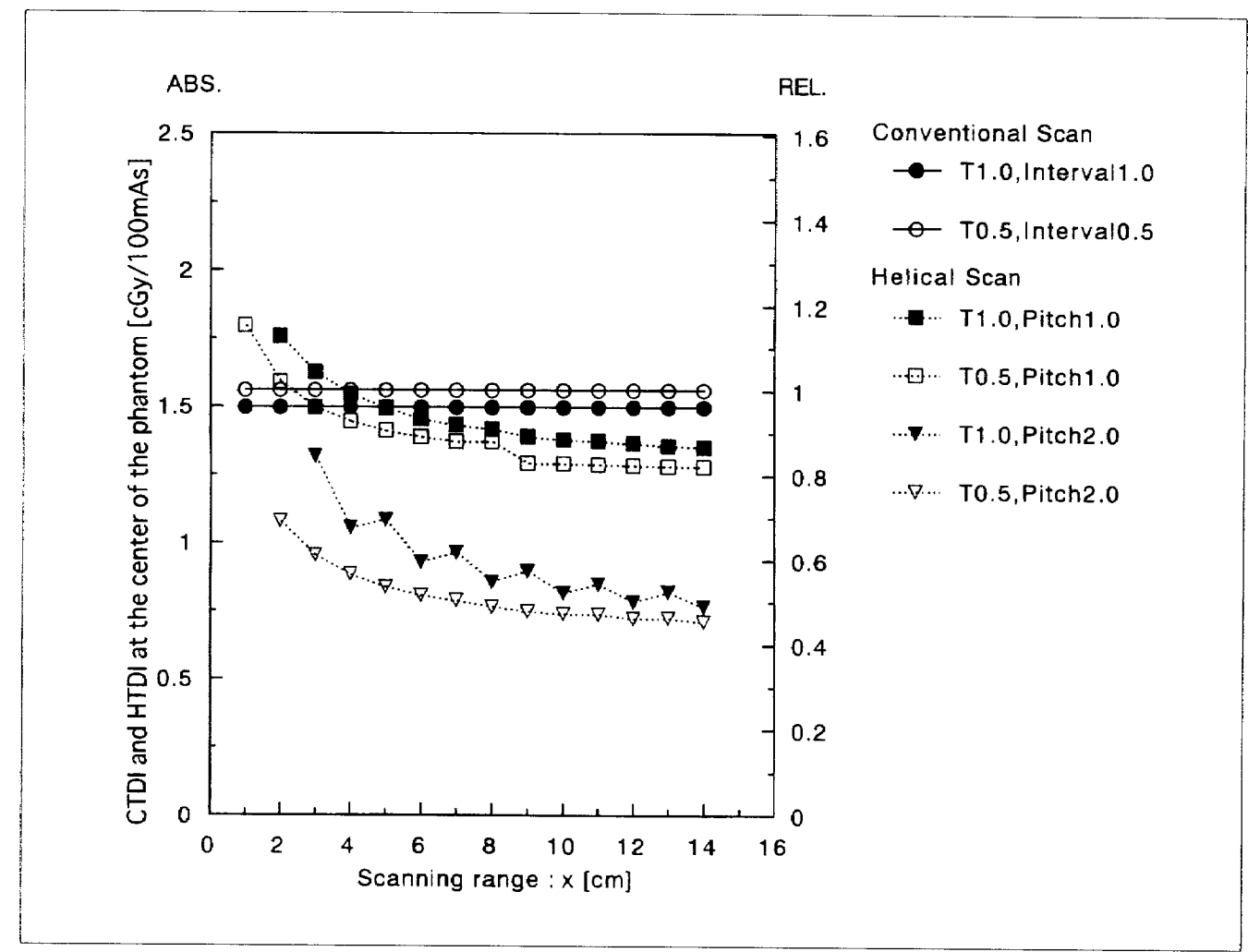

Fig. $5 \mathrm{HTDI}(\mathrm{x}) \mathrm{s}$ and CTDI $(\mathrm{x}) \mathrm{s}$ at the center of the phantom per $100 \mathrm{mAs}$ : comparison between slice thicknesses of $0.5 \mathrm{~cm}$ and $1 \mathrm{~cm}$

[Remarks]

Tube voltage : $120 \mathrm{kV}$

$T$ : Slice thickness

These are displayed in the same manner as in Figs. 3 and 4. 


$$
H T D I(x)=(1 / T) \cdot H(x)
$$

となる。ここで式 (6) (7)（8）をまとめると， スキャン 範囲 $x$ のときのHTDI $(\mathrm{x})$ は，2-3の中で記述した式(4) として導出できる.

$$
\begin{aligned}
\operatorname{HTDI}(x) & =(1 / \operatorname{Tm}(x)) \cdot I D_{\text {helical }}(x) \\
& =(1 /(x+T)) \cdot I D_{\text {helical }}(x)
\end{aligned}
$$

以上より，式(3) (4)からHTDI (x)は，スキャン範囲 をパラメータとして, CTDIに対して直接比較が可能 な線量指数と考えられる.

なお，本論文中ではHTDI $(\mathrm{x}) ， \operatorname{CTDI}(\mathrm{x})$ および積分 線量は，すべて $100 \mathrm{mAs}$ 当たりに換算した值で表示し た。各部位に扔ける通常のスキャン条件で測定・表示 する考え方もあるが，性能評価・管理上は $100 \mathrm{mAs}$ 当 たりに換算した値で示したほうが理解し易く，今後他 のCT装置との比較においても便利である。また今回 は200mAsを設定したが，CT装置に対する実験上の負 荷を考慮するならば，事前にCTDIとmAs值が正比例 の関係”にあることを確認した後，100mAsあるいはそ れ以下のmAs值で測定を行い，必要に応じて換算すれ ば問題はないと考える。

\section{4-3 HTDIの有用性について}

実際に算出されたHTDIの結果よりその有用性につ いて考察する.

性能評価上最も関心が持たれる，同一のスキャン範

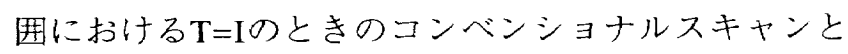
ヘリカルスキャンのピッチ1.0との線量比較を考え る。両スキャン条件下では4-1で述べた三つの線量因 子のうち, 補間再構成とX線スイッチングの二つの因 子が影響する。たとえば, Fig.3に示されたスライス 厚 $1 \mathrm{~cm}$ における両スキャン条件下の線量指数がスキャ ン範囲約 $5 \mathrm{~cm}$ を境に交差し逆転した現象は，スキャン 範囲が狭いときは，ヘリカルスキャンの補間再構成に よる線量堌加の影響が優位に作用することを示してい る。しかし，スキャン範囲が広くなるにつれて，両ス キャンにおけるX線スイッチングの回数差による線量 差が優位に作用し，その関係が逆転することを示すも のと考える。また，スライス厚 0.5 と $1 \mathrm{~cm} の$ 比較では, スライス厚 $0.5 \mathrm{~cm}$ の方がX線スイッチングの回数差の 影響がより顕著に現われる。そのため, 本使用CT装 置において同一スキャン範囲をスライス厚 0.5 と $1 \mathrm{~cm}$ でスキャンを行ったとき，Fig.5に示すように，コン ベンショナルではスライス厚 $1 \mathrm{~cm}$, またへリカルス キャンでは逆にスライス厚 $0.5 \mathrm{~cm}$ の方が線量指数が小
さくなる。なお，本使用CT装置では180度および 360 度補間再構成法が選択できるが, HTDI $(\mathrm{x})$ に変化はな かった。

では，実際的に $\mathrm{T}=1$ Iのときのコンベンショナルスキ ヤンとへリカルスキャンのピッチ1.0の線量はどれくら い違うのか. スライス14層分の範囲つまりスライス 厚 $1 \mathrm{~cm}$ ならばスキャン範囲 $14 \mathrm{~cm}$ に㧍いて, 片倉ら ${ }^{12,13)}$ は本使用CT装置に招ける比較で, 約 $15 \sim 20 \%$ 程度へ リカルスキャンの方が低い值となるとしている。ま た，著者らの以前の検討でも約 $20 \%$ 程度低い值になる と報告 ${ }^{(0)}$ した．今回の検討でもTableに示すように， コンベンショナルスキャンに対して約10～15\%程度へ

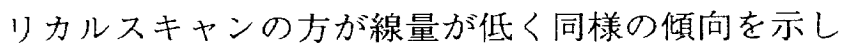
た。しかし, 文献と今回の測定結果ではその線量差に なぜ違いが見られたのか。この原因は，以下に述べる ように測定方法の違いによると考える．Fig.6にスキ ヤン範囲 $x$ に扔ける両スキャン条件下でのZ軸上の線 量プロフィールとTLDの配置との関係を模式図で示 す。な扔，この線量プロフィールは，従来のように患 者テーブルでファントムを固定したときの中心軸上の ものである，文献の中で，片倉らはTLDをZ軸方向に 複数個, 著者らはスキャン範囲の中心に 1 個のTLD素

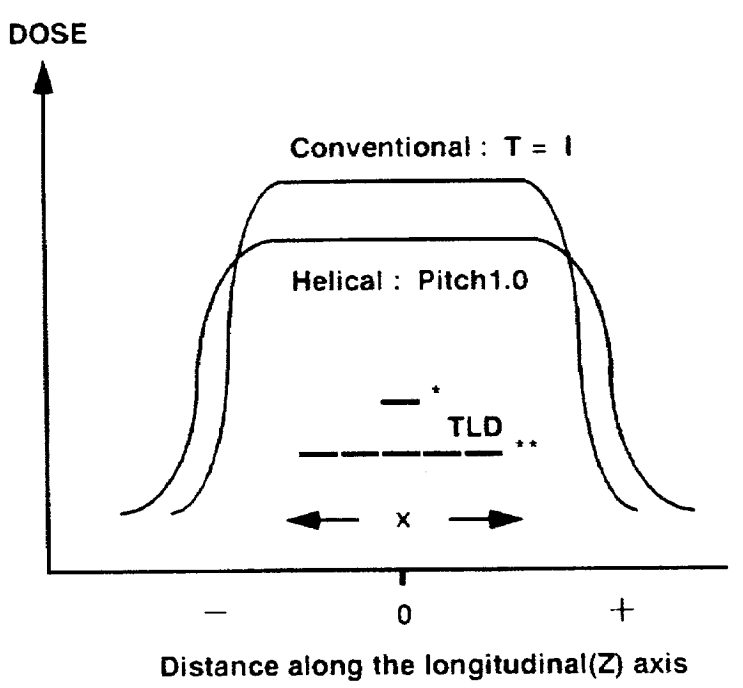

Fig. 6 Typical dose profile and location of TLDs on the longitudinal $(Z)$ axis at the center of the phantom. In the TLD method, dose is evaluated at the dosimeter position. In our method, on the other hand, the index dose is evaluated using a pencil-shaped ion chamber dosimeter.

[Remarks]

$T$ : Slice thickness

1 : Couchtop sliding interval $(\mathrm{cm})$ in conventional scanning.

$x$ : Scanning range

* Reference ${ }^{10)}$

** References ${ }^{12,13)}$ 
子を配置する万法で測定したとしている。このため, 測定值に対してX線のスイッチングの回数差は反映す るものの，スキャン範囲が広がるにつ机てへリカルス キャンの開始㧈上び終了時に生じる補間再構成による 線量増加分については反映学机にくくなると考えられ る。つまり，文献のTLDによる測定では，線量プロフ イール上に扔いてTLD素子が配置された位置の場の線 量が測定されるのに対し，今回考案したペンシル型電 離箱による測定では，線量プロフィール下の面積すな わち積分線量を測定しているからである。本論文は線 量測定法の優劣を評価することが目的ではないが，雨 スキャンにおいて同一スキャン範囲の画像情報を得る ときの線量比較つまりCT装置の性能評価という立場 では，本測定法は非常に合理的であるといえる。

以上より，スキャン範囲をパラメータとし表示する HTDIは，ヘリカルスキャンの線量特性を的確に表現 できる線量指数といえる。また，CTDIの規格を考慮 し，Tableに示すようにスライス14層分の範囲の上き のHTDIを代表值として測定す机ば，簡易的に線量特 性㧍よび臨床上の患者被曝の概略を知ることが可能で ある。

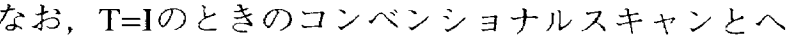
リカルスキャンのピッチ1.0の線量比較に対して今回 使用したCT装置に限って文献を提示したのは，P.L. McGheeらの報告14によ机ばSOMATOM Plus(株式会 社シーメンス旭メディテック製にに扔いては而スキャ ン条件下のZ蟿上の線量プロフィールに差異はなく,
従来のCTDIまたはMSADで評価が可能としているか らであるＨTDIによる線量評価の一般性を確認する 意味に扔いても，今後早急に機種間差について検討す る必要があると考える。

\section{5. おわりに}

ヘリカルスキャンに扔ける新しい線量評価法を考案 した．本法は，スキャン設定範囲をパラメータとして 積分線量の測定を行い，ヘリカルスキャンCTの線量 指数 (helical scanning CT dose index：HTDI)を算出す るものである。

本法の特長は,

1. 従来より沉用されている線量測定システムを応 用

2. HTDIは, CTDIおよびMSADと直接比較が可能

3.ヘリカルスキャンに特有の線量因子を評価する ことが可能なことである。

今後は，他機種にて本評価法の一般性を確認すると ともに，ヘリカルスキャンにおける線量評価規格とし て，各関連学会抢よび協会に提案したい。

\section{謝 辞}

本研究に際し，終始実験協力をいただいた秋山典子 氏(元国立がんセンター放射線診断部)に感謝します。

な扮本研究は, 厚生省新対がん10力年総合研究事業 の森山班（班長，森山紀之：国立がんセンター東病院） より研究助成を受けたことを記します。

\section{参考文献}

1) 真野 勇, 金子昌生, 竹中栄一, 他：Computed Tomography装置の基礎的研究 (第 8 報)。日本医放会誌，39(5)， 528-535, (1979).

2) ShopeTB, Gagne RM and Johnson GC: A method for describing the doses delivered by transmission $x$-ray computed tomography. Med.Phys., 8(4), 488-495, (1981).

3) FDA (Food and Drug Administration), $\$ 1020.33$ Computed Tomography (CT) equipment, 481-482, (1990).

4) Conway BJ, McCrohan JL, Antonsen RG, et al.: Average radiation dose in standard CT examinations of the head Results of the 1990 NEXT Survey. Radiology, 184, 135-140, (1992).

5) 鈴木 革：X線CT装置の照射線量の簡単な測定法。映像情 報，11(7)，486-488，(1979)。

6) Standardized Method for Measuring Diagnostic X-ray Exposures, AAPM Report No.31, 15-19, (1990).

7）村松禎久, 三塩宏二, 松田幸宏, 他：最近のCT装置の動向 一X線発生方式による被曝線量と低コントラスト分解能と の関係-。日放技学誌，50(1)，21-27，(1994).

8) 花井耕造, 井原完有, 藤田智之, 他：へリカルCTに拈ける
コントラスト分解能上最適画像再構成間隔に関する研究. 日放技学誌, 50(12)，1950-1959，(1994).

9) Polacin A, Kalender WA and Marchal G: Evaluation of section sensitivity profiles and image noise in spiral CT. Radiology, 185, 29-35, (1992).

10) 村松禎久：螺旋状(ヘリカル)スキャンの被曝線量は, どの ように測定すべきか一被曝形態からのアプローチー、日放 技学誌, 51(5)，642-644，(1995).

11 ) 遊佐 烈, 片倉俊彦, 鈴木憲二, 他：ヘリカルスキャンCT 被曝線量に関する一考察。日放技学誌，52(2)，125， (1996).

12) 木村和衛, 古賀佑彦: ヘリカルスキャンの基礎と臨床. pp.138-139, 医療科学社, 東京, (1993).

13）佐藤孝則，佐藤勝正，青山正勝，他：ヘリカルスキャンに よる胸部CTの被曝低减。日放技学誌，47(8)，1213， (1991).

14) McGhee PL and Humphreys S: Radiation dose associated with spiral computed tomography. Can.Assoc.Radiol.J., 45, 124 129, (1994). 